\title{
Copepods from intertidal interstitial water of Salvador, Brazil. I. Cuipora janaina gen. n., sp. n. \& Cyclopina caiala sp. n. (Cyclopoida: Cyclopinidae)
}

\author{
Guilherme Ribeiro Lotufo \& Carlos Eduardo Falavigna da Rocha \\ Departamento de Zoologia, Instituto de Biociências, Universidade de São Paulo, Caixa Postal 20520, \\ CEP 01498, São Paulo, Brasil
}

Keywords: Cyclopoida, Crustacea, taxonomy, new taxa, interstitial, Brazil

\begin{abstract}
Cuipora janaina gen. n., sp. n., and Cyclopina caiala sp. n. are described from the interstitial water of a sandy beach in Salvador, Bahia (Brazil).

Cuipora is distinguished from all other genera of the subfamily Cyclopininae in having the endopodite of legs 1-4 2 -segmented and the terminal segment armed with 4 setae.

Cuipora is compared to Erythropolites Huys \& Boxshall, 1990, Herbstina Huys \& Boxshall, 1990, and Cyclopina Claus, 1862 , with which it has most morphological similarities.

Cyclopina caiala sp. $\mathrm{n}$. is distinguished by the structure of the leg 5 of the male and female and by a particular combination of characters of the mouthparts. Taxonomical problems involving Cylopina mediterranea Steuer, 1940 are discussed.
\end{abstract}

\section{Résumé}

On décrit Cuipora janaina gen. n., sp. n., et Cyclopina caiala sp. n., de l'eau interstitielle d'une plage de sable à Salvador, Bahia (Brésil).

Cuipora se distingue de tous les autres genres de la sousfamille des Cyclopininae par l'endopodite des pattes 1-4 bisegmenté et par le segment terminal armé de 4 soies.

On compare Cuipora à Erythropolytes Huys \& Boxshall, 1990, Herbstina Huys \& Boxshall, 1990, et Cyclopina Claus, 1862 - genres avec lesquels les similarités dans la morphologie sont les plus marquées.

Cyclopina caiala sp. $n$. se distingue par la structure de la patte 5 du mâle et de la femelle, ainsi que par une combinaison particulière de caractères des appendices buccaux. Sont discutés les problèmes taxonomiques concernant Cyclopina mediterranea Steuer, 1940.

\section{Introduction}

Knowledge of the cyclopinids along the Brazilian coast is incomplete. Herbst (1955) provided the only records of these copepods in Brazil. He described two new species (Cyclopinopsis braziliensis and Procyclopina polyarthra) and identified some specimens of Cyclopina cf. steueri from samples taken from sandy beaches on Ilhabela, São Sebastião Island.

Bregari Beach in Salvador, Bahia, supports a very diverse interstitial fauna, as we could verify. Among the most abundant forms are several species of harpacticoid and cyclopoid copepod. Two new species of Cyclopininae Kiefer (1927) are described here. One belongs to the genus Cyclopina Claus, 1862. Since the other new species does not fit any of the 30 known genera (Huys \& Boxshall, 1990), a new genus is proposed to accommodate it.

\section{Material and methods}

The copepods were collected in the phreatic interstitial water (depth $20 \mathrm{~cm}$ below surface) on the sandy beach. Interstitial water collected in holes dug on the beach was filtered through a $200 \mu \mathrm{m}$ mesh, and animals retained were fixed in $4 \%$ formalin. Granulometric analysis was not carried out, but coarse sand and shell fragments were the main sediment components. Amphioxus (Cephalochordata) were found in the same samples.

Intact specimens were examined in $85 \%$ lactic acid and dissected parts were placed in slides sealed with Glyceel. The terminology applied to segmentation of the mouthparts follows that of Huys \& Boxshall (1990). 


\section{Taxonomic part}

\section{Cuipora gen n.}

Diagnosis. - Cyclopininae. Pediger 1 partly fused to cephalosome. Antennule 9-segmented in female, 14-segmented in male. Exopodite of antenna represented by 1 seta. Mandible with 2-segmented endopodite and 4-segmented exopodite. Maxilla 6-segmented. Endopodite of maxilliped 4-segmented. Legs 1-4: endopodite 2-segmented; exopodite 3 with $4,4,4,3$ spines and 4,5,5,5 setae; exopodite 1 and 2 with reduced inner seta; endopodite 2 with 4 setae. Leg 5 of male and female 2-segmented; exopodite with medial apical seta and 2 spines. Leg 6 of male with 2 setae and 1 spiniform projection.

Type-species. - Cuipora janaina sp. n.; by monotypy.

Etymology. - The generic name is derived from the Tupi-Guarani language, "cui" meaning sand and "pora" meaning inhabitant.

\section{Cuipora janaina gen. n., sp. n}

(Figs. 1-15)

Material examined. - Bregari beach, Salvador, Brazil, 55 १ and $40 \sigma^{\circ} \circ, 4$ Nov. 1985, C.E.F. Rocha col. The $\&$ holotype and 20 paratypes are deposited in the collection of the Museu de Zoologia, Universidade de São Paulo (MZUSP 10737 and 10738, respectively).

Description. - Female. Body length 440-500 $\mu \mathrm{m}$. Prosome : urosome ratio $=1.15: 1$. Pediger 1 apparently separated from cephalosome in dorsal view (Fig. 1), but more accurate examination reveals the somite being fused to the cephalosome laterally in distal corners (Fig. 2); lines persisting between cephalosome and pediger 1 interpreted as scars. Genital segment longer than wide, with 2 anterolateral protuberances, both conspicuously thickened and with 1 seta (Fig. 1).

Caudal ramus (Fig. 3) longer than anal somite and about 2.4 times longer than wide. Inner median apical seta about 1.5 times longer than outer median apical seta, both spinulose proximally and plumose distally. Inner apical seta 1.5 times longer than outer apical seta. Lateral seta as long as outer apical seta, and apparently naked.

Antennule (Fig. 4) 9-segmented. Armament as follows (Roman numeral = segment; Arabic numeral = setae; $\mathrm{sp}=$ spine; ae $=$ aesthetasc): $\mathrm{I}-3$; II-5; III-7; IV-3 + sp; V-4; VI-2; VII-2; VIII-2 + ae; IX-7 + ae. Apical aesthetasc fused at base to adjacent seta.

Antenna (Fig. 5) 4-segmented. Segment 1 comprised of fused coxa and basis, armed with 1 inner seta distally and 1 outer seta representing exopodite. Endopodite 1 with 1 marginal seta, endopodite 2 with 5 setae, and endopodite 3 with 7 apical setae and row of 5 small lateral setae.

Mandibular palp (Fig. 6) consisting of wide basis bearing inner seta; endopodite 2-segmented, with 2 and 5 setae on basal and terminal segments; exopodite 4-segmented, with 1 seta on segments $1-3$ and 2 setae on segment 4 .

Maxillule (Fig. 7) with biramous palp. Coxa without outer seta representing epipodite. Basis with 2 setae on proximal endite and 1 seta on distal endite. Exopodite 1-segmented, with 4 setae on distal margin. Endopodite 1-segmented with 5 setae on distal margin and 2 setae on inner margin.

Maxilla (Fig. 8) 6-segmented, comprised of praecoxa, coxa, basis and 3-segmented endopodite. Praecoxa with proximal endite bearing 3 setae and distal endite with 1 seta. Coxa with 2 endites: proximal endite with 1 seta and distal endite with 3 setae. Basis bearing 2 broad setae and 1 very slender seta. Endopodite bearing 3, 2, and 3 setae on segments $1-3$, respectively.

Maxilliped (Fig. 9) 6-segmented, comprised of syncoxa, basis and 4-segmented endopodite. Syncoxa with 2 endites; proximal endite with 3 setae and distal endite with 2 setae. Basis enlarged, armed with 2 setae. Endopodal segment 3 with short seta; segment 4 with 1 short and 2 long setae; other endopodal segments naked.

Swimming legs 1-4 (Figs. 10-12) having 2-segmented endopodite (scar of fusion between former endopodites 2 and 3 only visible in the outer side of endopodite leg 1) and 3-segmented exopodite; con- 


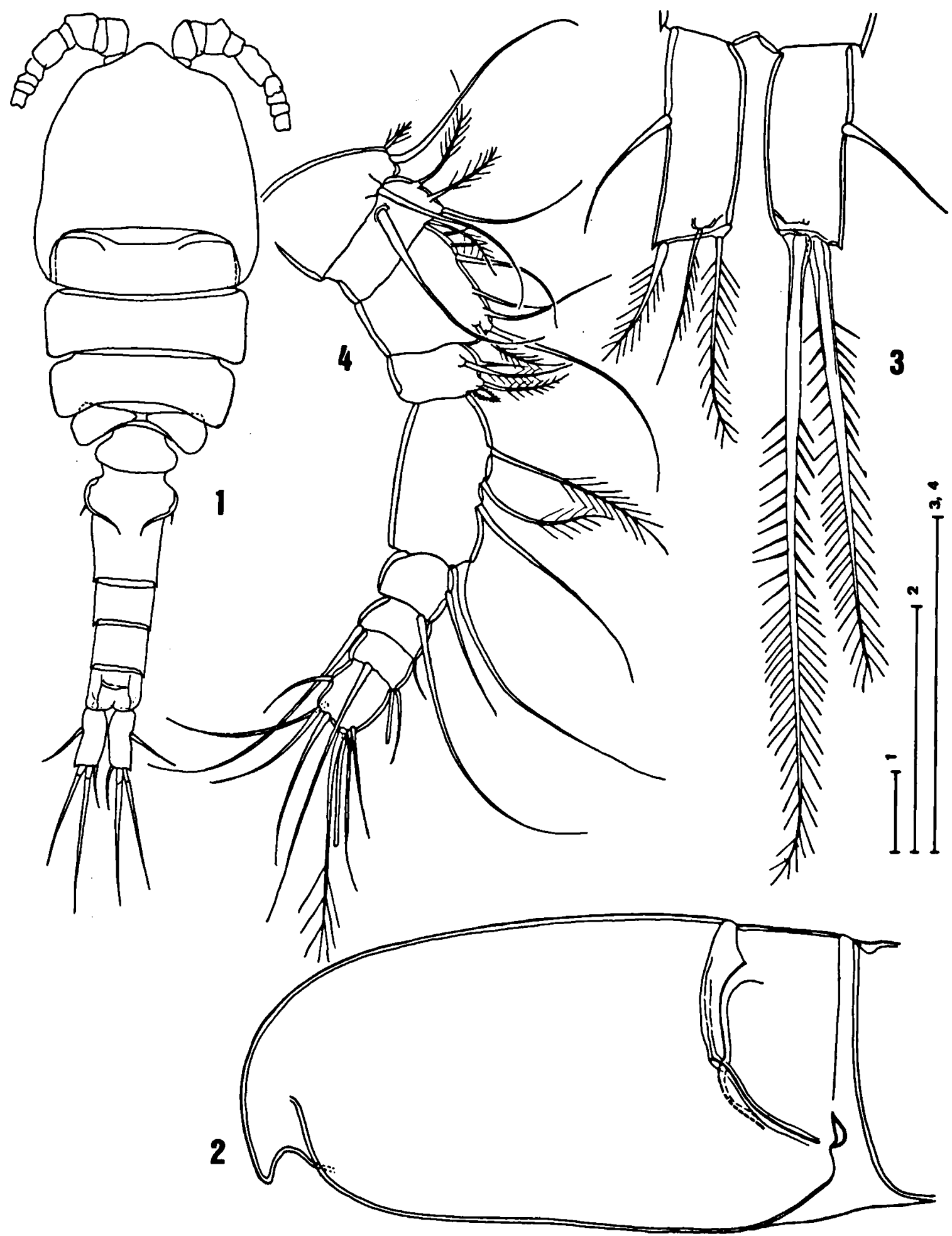

Figs. 1-4. Cuipora janaina gen. n., sp. n., $९$ holotype: 1, habitus, dorsal; 2 , cephalosome and first pediger showing the scars representing limits between both segments, left lateral; 3, caudal rami, dorsal; 4, antennule. Scale bars $50 \mu \mathrm{m}$. 

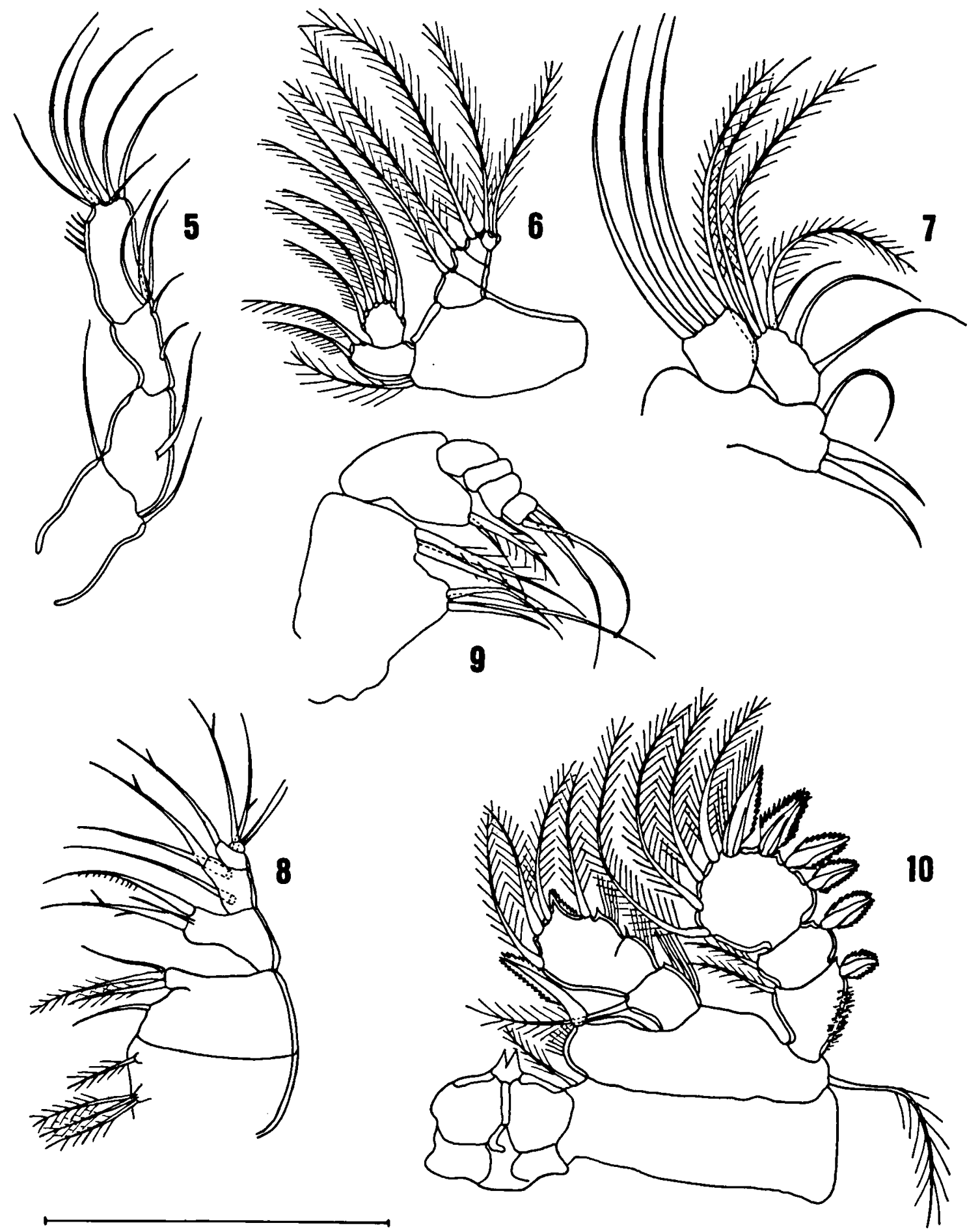

Figs. 5-10. Cuipora janaina gen. n., sp. n., $९$ holotype: 5, antenna; 6, mandibular palp; 7, maxillular palp; 8, maxilla; 9, maxilliped; 10, leg 1 . Scale bar $50 \mu \mathrm{m}$. 
figuration of spines and setae as shown below. Leg 2 (not figured) differing from leg 3 in size and in having slender spines. Distalmost spine on leg 1 exopodite 3 with inner margin plumose and outer margin serrate. Inner and apical setae on leg 4 endopodite 2 reduced in length and densely plumose. Endopodite 2 of legs 1-4 with serrate hyaline membrane along margin distal to outer seta. The armament of legs $1-4$ is as follows:

$\begin{array}{lllll} & \text { COXA } & \text { BASIS } & \text { EXOPODITE } & \text { ENDOPODITE } \\ \text { P1 } & 0-1 & 1-I & \text { I-1; I-1; IV-4 } & 0-1 ; 1,2,1 \\ \text { P2 } & 0-1 & 1-0 & \text { I-1; I-1; IV-5 } & 0-1 ; 1,2,1 \\ \text { P3 } & 0-1 & 1-0 & \text { I-1; I-1; IV-5 } & 0-1 ; 1,2,1 \\ \text { P4 } & 0-1 & 1-0 & \text { I-1; I-1; III-5 } & 0-1 ; 1,2,1\end{array}$

Leg 5 (Fig. 13) composed of 2 segments, proximal segment with long outer seta, distal segment 1.6 times longer than wide and bearing 2 spines and 1 seta, outer spine small and with serrate lamella, inner spine twice as long as outer spine and naked. Median seta about 3 times as long as distal segment. Narrow intercoxal plate joining both 5 th swimming legs.

Male (Fig. 14): Body length 415-490 $\mu \mathrm{m}$. Ratio prosome : urosome $=1.2: 1$. Antennule 14-segmented. Leg 5 (Fig. 15) similar to that of the female, except that both spines have a serrate lamella. Leg 6 (Fig. 15) represented by inner spiniform projection and 2 setae, outermost seta being twice as long as median seta.

Etymology. - The specific name honors Janaina, "spirit" of the Brazilian Candomblé and Yoruban pantheons, patroness of love and those who go to sea.

Discussion. - An up-to-date key for the genera of Cyclopininae was presented by Huys \& Boxshall (1990). Cuipora gen. n. can be included in item 6 of this key as follows:

6. Exp3. P1-P4 with $8,9,9,8$ spines/setae; enp2. P1-P4 with 4,5,5,5 spines/setae; A1 female 8-segmented .......... .............. Erythropolites Huys \& Boxshall, 1990

- Exp3. P1-P4 with 8,9,9,8 spines/setae; enp2. P1-P4 with 4,4,4,4 spines/setae; A1 female 9-segmented
Cuipora gen. $\mathbf{n}$.

- Exp3. P1-P4 with 7,9,7,7 spines/setae; enp2. P1-P4 with 4,3,4,4 spines/setae; Al female 6-segmented .......... Indocyclopina Wells, 1967

Most of the characters enumerated in the diagnosis of Cuipora gen. $n$. were established by Lindberg $(1953,1961)$ as a basis for the erection of a new genus of the Cyclopininae. Other characters were added following Huys \& Boxshall (1990) to improve the diagnosis. Cuipora is distinguished by a combination of the states of these characters not found in any of the other genera.

Two-segmented endopodites in legs 1 to 4 are found in five other genera of this subfamily. Among them, Indocyclopina Wells, 1967, Erythropolites Huys \& Boxshall, 1990, and Herbstina Huys \& Boxshall, 1990 have 3-segmented exopodites in these legs. Cuipora is the only genus that has 2-segmented endopodites together with 4 setae on each distal segment of the endopodites of the swimming legs.

Erythropolites shares with Cuipora other characters than the segmentation of the swimming legs. These are the segmentation of the mandibular palp, the spine and setal formula of legs $1-4$ exopodite segment 3, and the structure of leg 5 in the female. Erythropolites differs in possessing an 8-segmented antennule and a 3-segmented endopodite of the maxilliped, in lacking the seta representing the exopodite on the antenna, in possessing 5 setae on the endopodite of the maxillula and in bearing 4 elements in the distal article of the leg 5 of the male.

Herbstina shares with Cuipora the number of segments in the antennule and mandibular palp and the number of elements in leg 5 of the female. Herbstina differs in lacking the antenna exopodite, in having the maxilliped with 2-segmented endopodite, legs 1-4 exopodite segment 3 having spine and setal formula 3-3-3-3 and 5-5-5-5 respectively, and in having the exopodite of leg 5 with 6 setae and leg 6 with 3 elements in the male.

Cyclopina Claus, 1862 is another genus closely related to Cuipora. The body shape is similar in both genera. The structure of antenna and mouthparts in Cuipora is exactly as in Cyclopina caiala sp. n. (discussed below) except for the 6-segmented 

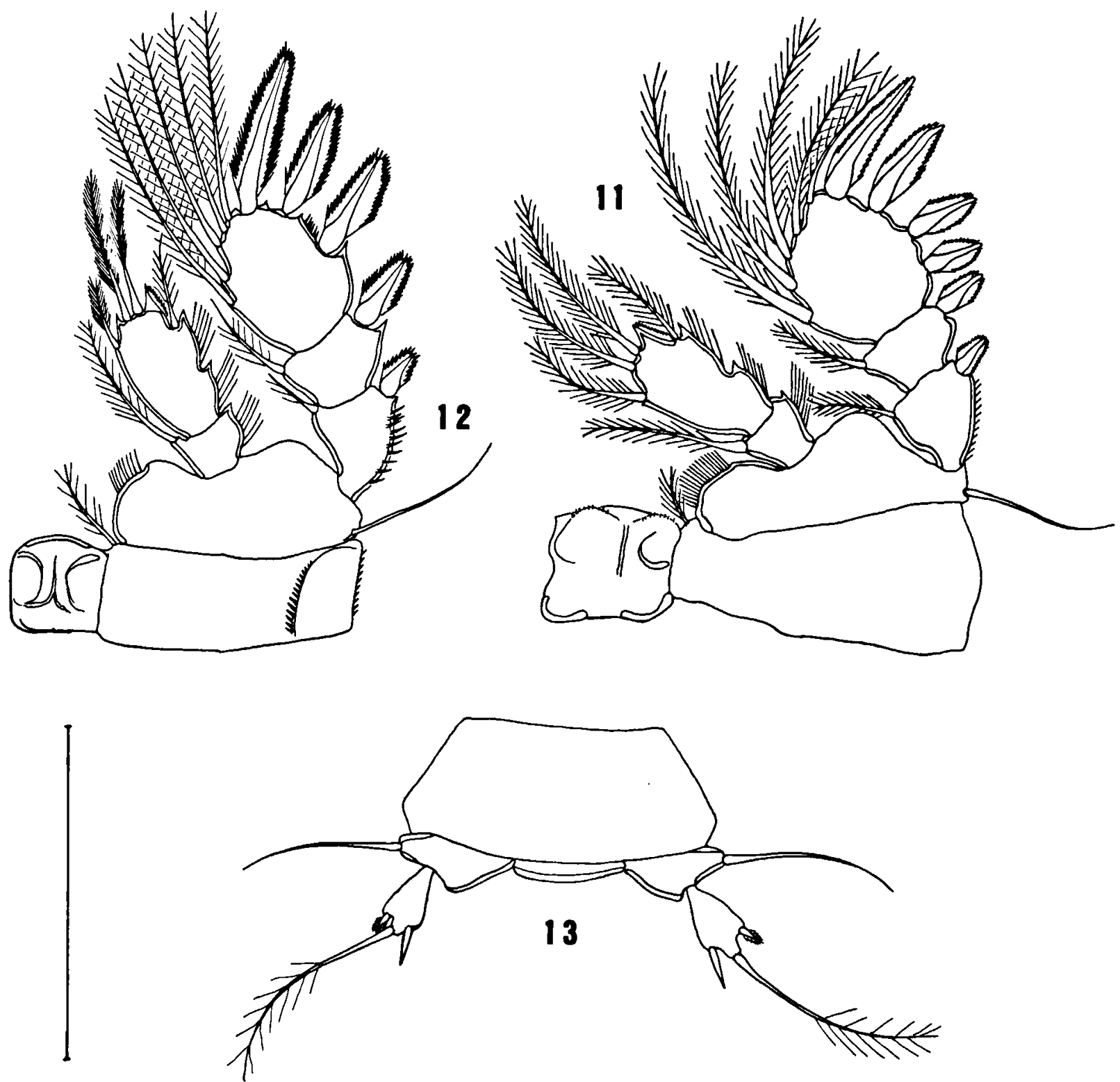

Figs. 11-13. Cuipora janaina gen. n., sp. n., \& holotype: 11, leg 3; 12, leg 4; 13, pair of leg 5 . Scale bar $50 \mu \mathrm{m}$.

maxilla and the armament of the maxillipedal endopodite. The spine and setal formula of legs $1-4$ exopodite 3 and the structure of leg 5 in the male and female described for Cuipora are widely found in species of Cyclopina and in other genera of Cyclopininae as well. However, the differences in the segmentation and armament of legs $1-4$ and in the number of segments in the antennula necessitate the separation of this species in a new genus.
Cyclopina caiala sp. $n$.

(Figs. 16-30)

Material examined. - Bregari beach, Salvador, Brazil, 22 ㅇ and $18 \sigma^{\circ} \circ, 4$ Nov. 1985, C.E.F. Rocha col. The $Q$ holotype and 12 paratypes are deposited in the collection of the Museu de Zoologia, Universidade de São Paulo (MZUSP 10739 and 10740, respectively). 


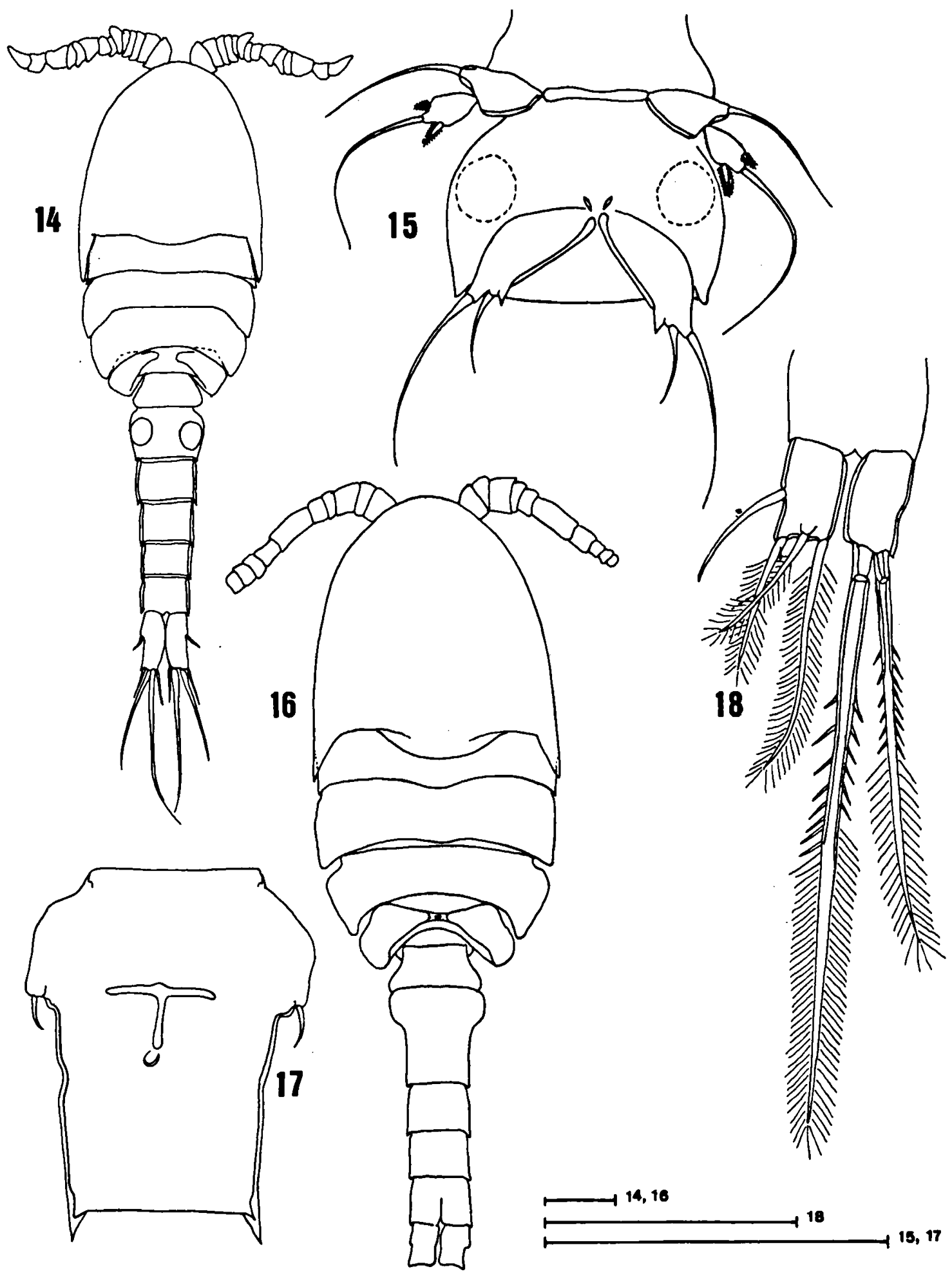

Figs. 14-15. Cuipora janaina gen. n., sp. n., o paratype: 14, habitus, dorsal; 15, first urosomite and genital somite with pairs of leg 5 and leg 6, ventral.

Figs. 16-18. Cyclopina caiala sp. n., $\$$ holotype: 16, habitus, dorsal; 17, genital segment with seminal receptacle, ventral; 18 , caudal rami, dorsal. Scale bars $50 \mu \mathrm{m}$. 


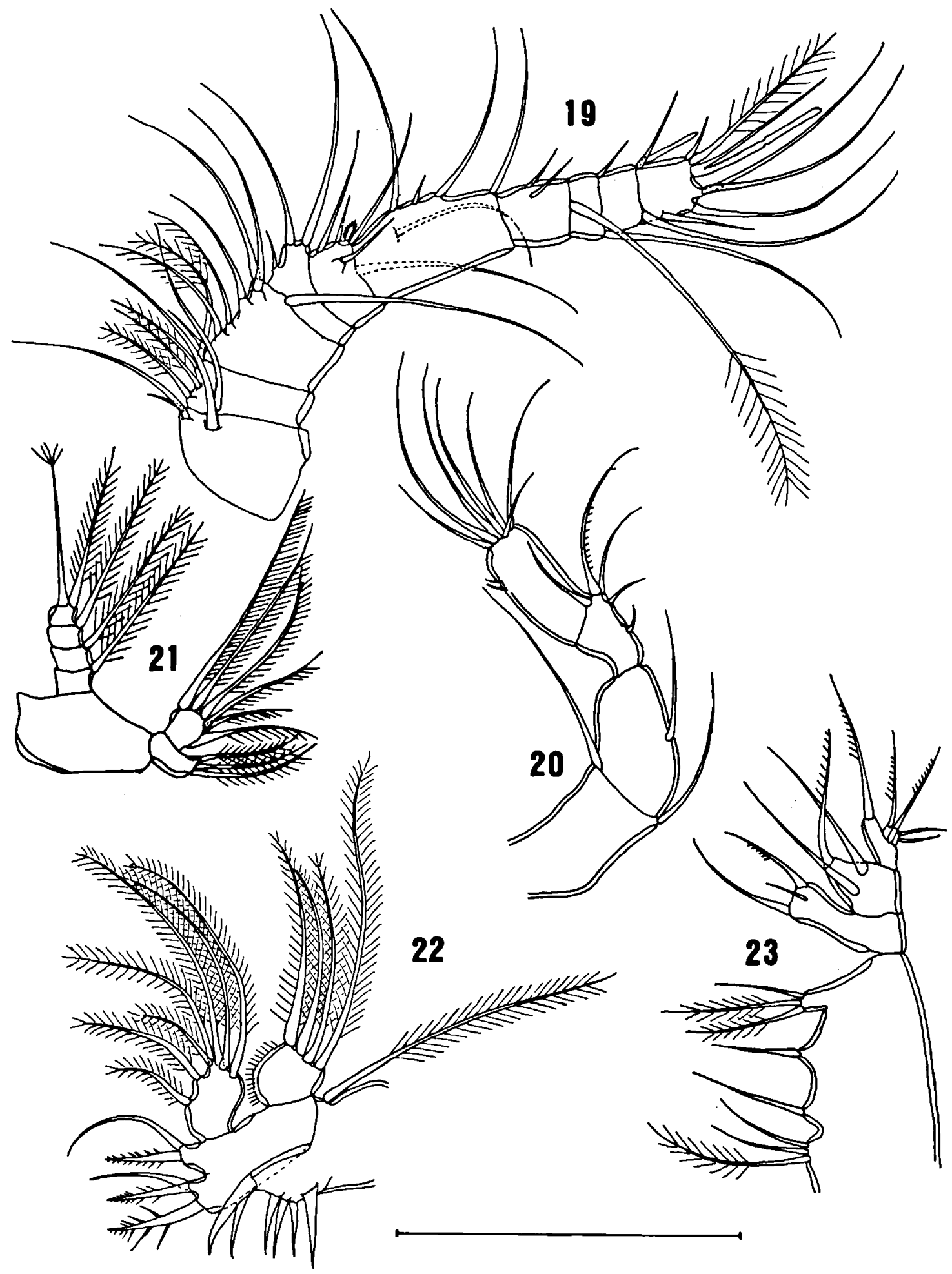

Figs. 19-23. Cyclopina caiala sp. n., \& holotype: 19, antennule; 20, antenna; 21, mandibular palp; 22, maxillule; 23, maxilla. Scale bar $50 \mathrm{um}$. 


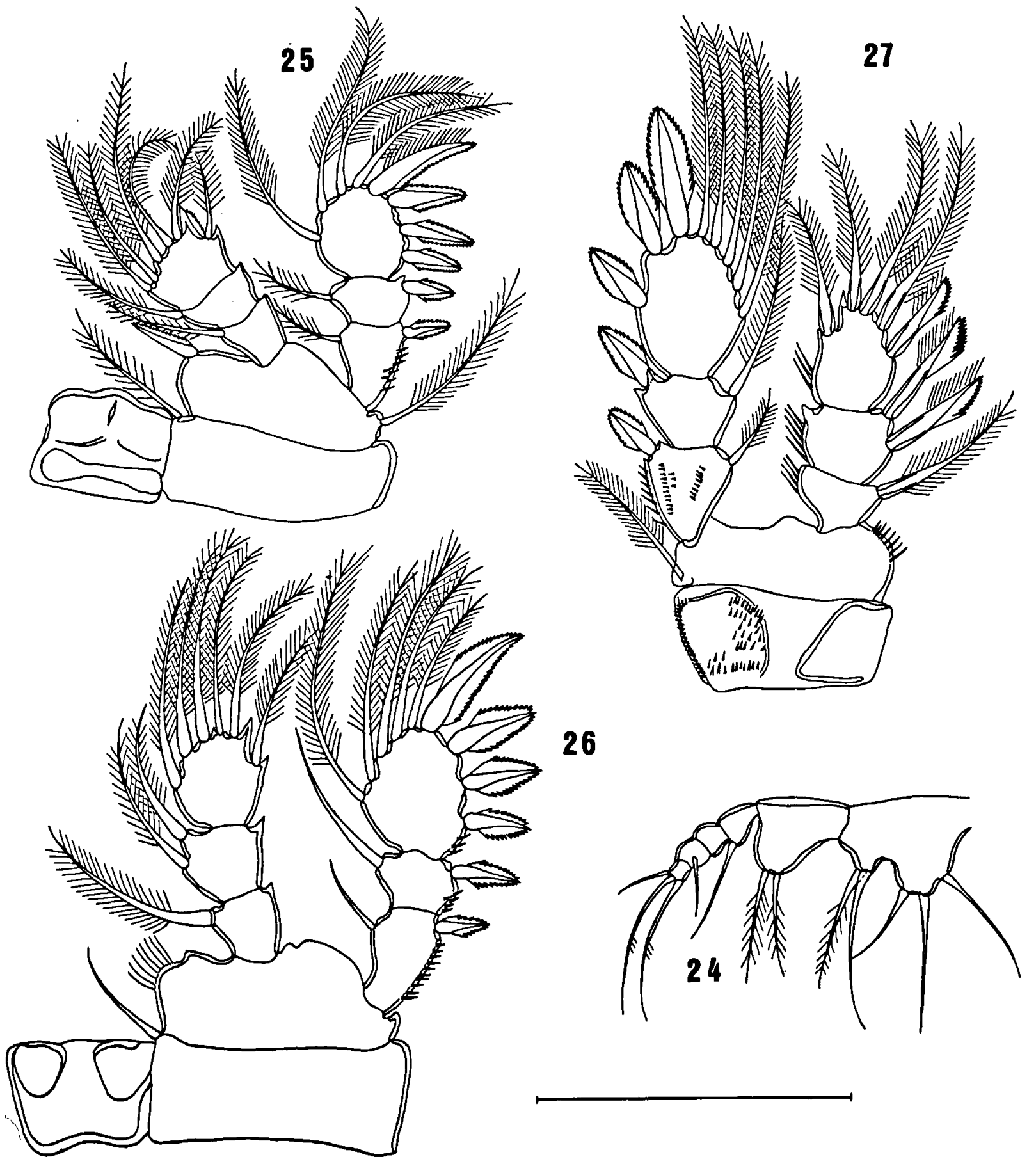

Figs. 24-27. Cyclopina caiala sp. n., $\odot$ holotype: 24 , maxilliped; 25, leg 1; 26, leg 2; 27, leg 4 (caudal face). Scale bar $50 \mu \mathrm{m}$. 


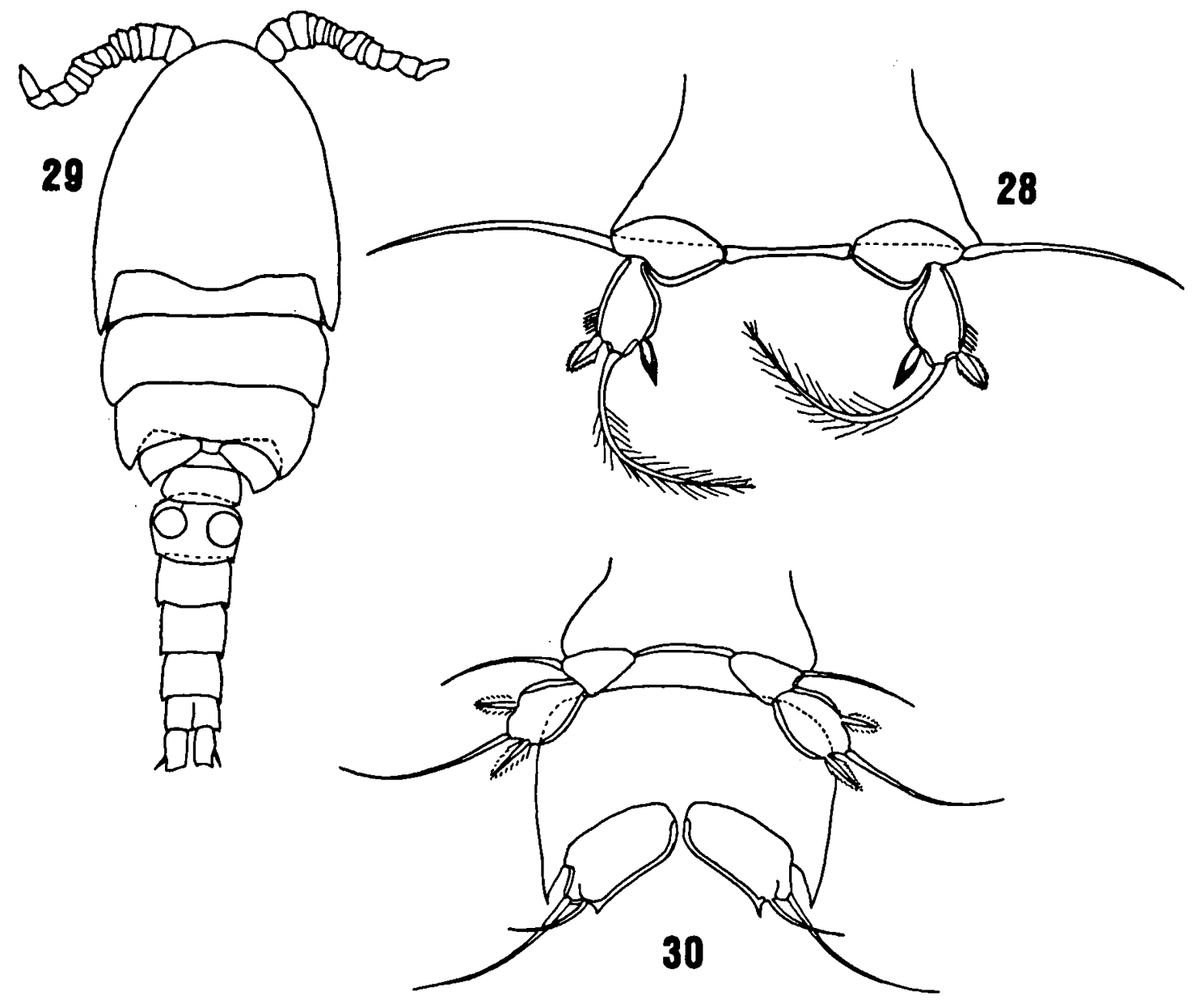

2830

Figs. 28-30. Cyclopina caiala sp. n.; 28, first urosomite $\odot$ holotype with pair of leg 5, ventral; 29, habitus $\sigma$ paratype, dorsal; 30, first urosomite and genital somite $\sigma$ with pairs of leg 5 and leg 6 , ventral. Scale bars $50 \mu \mathrm{m}$.

Description. - Female: Body length 430-520 $\mu \mathrm{m}$. Ratio prosome:urosome $=1.3-1.5: 1$. Suture between cephalosome and pediger 1 more visible laterally than mediodorsally. Pediger 4 with cuticular thickening on tergite (Fig. 16). Genital segment (Fig. 17) expanded anteriorly and tapering posteriorly. Seminal receptacle anchor-shaped. Caudal ramus (Fig. 18) 1.7 times longer than wide. Inner median apical seta 1.6 times longer than outer median apical seta; both setae spinulose proximally and plumose distally. Lateral seta, dorsal seta and outermost apical seta similar in length; innermost api- cal seta 1.7 times longer than outermost apical seta.

Antennule (Fig. 19) 10-segmented. Armament as follows (Roman numeral = segment; Arabic numeral = setae; $\mathbf{s p ~ = ~ s p i n e ; ~ a e ~ = ~ a e s t h e t a s c ) : ~} I$ $=3 ; \mathrm{II}=5 ; \mathrm{III}=7 ; \mathrm{IV}=3 ; \mathrm{V}=5+\mathrm{sp} ; \mathrm{VI}=$ 5; VII = 3; VIII = 2; IX $=2+$ ae; $X=7+$ ae.

Antenna (Fig. 20) 4-segmented; major armament as in Cuipora janaina.

Mandibular palp (Fig. 21): endopodite 1 with 3 setae; endopodite 2 with 6 setae; exopodite 4-segmented, each segment with 1 seta, except distal segment with 2 apical setae, of which outermost 
seta straight and tipped with tuft of hairs.

Maxillule (Fig. 22) with 2-segmented protopodite. Praecoxa fused to coxa; coxa and basis distinct. Praecoxal arthrite not clearly seen. Coxa with 1 outer seta representing epipodite. Basis with 2 endites: proximal endite with 3 setae and distal endite with 2 setae. Endopodite 1-segmented, with 5 setae on distal margin and 2 setae on inner margin. Exopodite 1-segmented, with 4 setae on distal margin.

Maxilla (Fig. 23) 5-segmented. Armed as in Cuipora janaina, differing by having praecoxa and coxa fused.

Maxilliped (Fig. 24) 6-segmented; syncoxa with 3 setae on proximal endite and 2 setae on distal endite. Basis expanded into endite with 2 setae. Endopodite 4-segmented; segment 1 with 1 seta, segment 2 naked, segment 3 with 1 seta, and segment 4 with 3 setae.

Legs 1-4 (Figs. 25-27) with 3-segmented rami. Leg 3 (not figured) differing from leg 2 in size and in having broader spines on exopodite 3 . Formula of spines for legs 1-4 exopodite 34-4-4-3 and of setae 4-5-5-5. Distalmost spine of exopodite 3 leg 1 plumose on inner margin and serrate on outer margin. Two setae of leg 4 endopodite 2 and proximalmost inner seta of endopodite 3 modified, spiniform, plumose on outer margin and with serrate hyaline lamella on distal half of inner margin; basipodites 1 and 2 and exopodite 1 bearing several rows of spinules on caudal face.

Leg 5 (Fig. 28) 2-segmented. Basal segment bearing long outer seta. Terminal segment twice longer than wide. Spines of terminal segment similar in length and about half length of segment. Ornamentation of these spines differing, outer spine bearing more conspicuous lamella. Apical seta about 5 times longer than spines. Narrow intercoxal plate joining both 5 th legs.

Male (Fig. 29): Body length 390-415 $\mu \mathrm{m}$. Ratio prosome : urosome $=1.6: 1$. Antennule with 15 segments. Leg 5 (Fig. 30) differing from that of female in having outer spine shorter than inner spine and inner spine with more conspicuous lamella. Leg 6 (Fig. 30) represented by inner spiniform projection and 2 setae, outer seta twice as long as inner seta.
Etymology. - The specific name refers to "Caiala", a local folkloric name given to the Siren "Queen of the Sea".

Differential diagnosis. - Cyclopina caiala sp. $\mathrm{n}$. is included in the group of species which possess reduced spines on the terminal segment of leg 5 .

Cyclopina caiala sp. $\mathrm{n}$. resembles Cyclopina mediterranea Steuer, 1940, Cyclopina vachoni Nicholls, 1939, and Cyclopina oblivia Monchenko, 1981 by the general structure of leg 5 in the female. The new species differs from the two latter species in the armament of the mandibular palp, maxillule, and maxilliped, the number of segments as well as the armament of the maxilla, and in having modified setae on endopodites 2 and 3 of leg 4. Cyclopina caiala can be distinguished from Cyclopina mediterranea in having no sexual dimorphism in leg 5, according to Steuer's (1940) description. In addition, Petkovski (1955) described the maxilliped of Cyclopina mediterranea as possessing 6, 3, 0, 0, 1, and 3 setae from the proximal to distal segments; Cyclopina caiala has a different formula for this mouthpart (5-2-1-0-1-3).

The terminal segment of leg 5 of Cyclopina caiala is very similar to that of the single female specimen from the Red Sea identified by Herbst (1964) as possibly Cyclopina latipes mediterranea Steuer, 1940. However, Herbst's specimen differs from $C$. caiala by the armament of the endopodites of the mandibular palp, maxillule, and maxilliped. Steuer (1940) presents an incomplete description of C. latipes mediterranea, mentioning only characteristics of the caudal ramus and leg 5 as differences from C. latipes Schäfer, 1936. Lindberg (1953) raised Steuer's (1940) subspecies to species level. Petkovsky (1955) redescribed $C$. mediterranea from specimens collected in Budva and Bar (Yugoslavia). The specimen identified by Herbst (1964) as possibly $C$. latipes mediterranea differs from Petkovsky's redescription in the general aspect of leg 5 of the female and the armament of the mandibular palp, maxillule, and maxilliped. To clarify this situation, it would be helpful to examine typematerial of $C$. mediterranea. It is likely that Herbst's (1964) specimen represents a new taxon. 


\section{Acknowledgments}

We are grateful to Dr. Janet Reid for reading the manuscript and for improving the English text and to Levi Ciobotariu for inking the line drawings.

\section{References}

Claus, C., 1862. Untersuchungen über die Organisation und Verwandtschaft der Copepoden. Verh. phys.-med. Ges. Würzb., 3: 51-103.

Herbst, H.V., 1955. Cyclopoida Gnathostoma (Crustacea, Copepoda) von der Brasilianischen Atlantikküste. Kieler Meeresforsch., 11(2): 214-229.

Herbst, H.V., 1964. Cyclopoida Gnathostoma (Crustacea, Copepoda) aus dem Litoral und Küstengrundwasser des Roten Meeres. Kieler Meeresforsch., 20 (Suppl.): 155-169.

Huys, R. \& G.A. Boxshall, 1990. The rediscovery of Cyclopicina longifurcata (Scott) (Copepoda: Cyclopinidae) in deep water in the North Atlantic, with a key to genera of the subfamily Cyclopininae. Sarsia, 75(1): 17-32.

Lindberg, K., 1953. La sous-famille des Cyclopininae Kiefer
(Crustacées Copépodes). Ark. Zool., (B)4(16): 311-325.

Lindberg, K., 1961. Une Cyclopinina nouvelle du sable de la côte Atlantique du Portugal. K. fysiogr. Sällsk. Lund Förh., 31(13): 127-132.

Monchenko, V.I., 1981. Cyclopina oblivia sp. n. (Crustacea, Copepoda) from the interstitial of the Black Sea. Vestnik Zool., 1981 (5): 10-16.

Nicholls, A.G., 1939. Marine harpacticoids and cyclopoids from the shores of the St. Lawrence. Station Biologique du Saint-Laurent. Fauna et Flora Laurentianae, 2. Naturaliste can., 66: 241-316.

Petkovski, T.K., 1955. IV Beitrag zur Kenntnis der Copepoden. Acta Mus. maced. Sci. nat., (3) 3: 71-104.

Schäfer, H.W., 1936. Cyclopiniden (Crustacea, Copepoda) aus der deutschen Nordsee. Zool. Anz., 114: 225-234.

Steuer, A., 1940. Über einige Copepoda Cyclopoida der mediterranen Amphioxussande. Note Ist. italo-germ. Biol. mar. Rovigno, 2(17): 1-27.

Wells, J.B.J., 1967. The littoral Copepoda (Crustacea) of Inhaca Island, Mozambique. Trans. r. Soc. Edinburgh, 67(7): 189-358.

Received: 10 November 1990

Revised: 19 February 1991 